\title{
Physician migration at its roots: a study on the emigration preferences and plans among medical students in Romania
}

\author{
Şoimita Mihaela Suciu', Codruta Alina Popescu ${ }^{2 *}$ (D), Mugur Daniel Ciumageanu ${ }^{3}$ and Anca Dana Buzoianu ${ }^{4}$
}

\begin{abstract}
Background: Migration of healthcare workers is receiving increased attention worldwide. In Europe, the creation of a border-free labor market and its expansion with the EU enlargements of 2004, 2007, and 2013 endowed health professionals with the right to provide services and to relocate to another EU Member State. For the Romanian doctors, the EU-wide recognition of the medical degree obtained in Romania has created new opportunities, while inadequate working conditions and relatively low salaries pushed many of them to search for employment abroad. As there is considerable uncertainty about the magnitude of the Romanian physicians' exodus, we performed a survey to assess the emigration intention of future Romanian doctors.

Methods: The study was conducted over three consecutive years: 2013, 2014, and 2015 at the University of Medicine and Pharmacy "Iuliu Hatieganu" Cluj-Napoca, Romania. The self-administrated questionnaire included 19 questions regarding students' emigration intentions.

Results: All the 957 license-degree students participated in the study. In this study, 84.7\% of subjects planned on seeking employment abroad after graduation. A large number of the students who have participated in the study have already started preparing for emigration, $21.7 \%$ of those who wished to migrate had already performed at least one Erasmus mobility in their country of choice, $44.5 \%$ have been enrolled in a language course, and $42.7 \%$ have searched for jobs on the Internet.

Conclusions: The majority of Romanian medical students considering migration see it as a serious alternative to the continuation of their professional training started in Romania. The findings of this study are upsetting and can impact both policy crafting and future research. Structural reforms in the healthcare provisions are needed in order to facilitate the retention of medical personnel. Romanian policy makers need to devise a comprehensive national health workforce plan to deal with physician migration.
\end{abstract}

\section{Background}

The challenges of health professional mobility and migration are not new: they have been identified and observed across decades since the first reports had been published in 1978 [1]. The demand on human resource in medicine is rapidly growing worldwide for a number of demographic and epidemiological conditions [2]. Health workers are under pressure for a number of reasons: high cost of training, attrition, migration, and

\footnotetext{
* Correspondence: cpopescu@umfcluj.ro

${ }^{2}$ Department of Abilities-Human Sciences, "Iuliu Hatieganu" University of Medicine and Pharmacy, Victor Babes Nr 8 Street, 400012 Cluj-Napoca, Romania

Full list of author information is available at the end of the article
}

increasing demand in the aging population. The main migration flow of health workers is from less developed countries to more developed ones, a fact known as "brain drain" [3]. There is an established connection between an adequate level of staffing and positive healthcare outcomes [4].

The migration patterns and the extent of healthcare professionals' migration from the developing countries to the developed countries has been a constant focus for research [5-7].

In Europe, the creation of a border-free labor market and its expansion with the EU enlargements of 2004, 2007, and 2013 endowed health professionals with the 
right to provide services and to relocate to another EU Member State [8].

Surveys to analyze the migration intentions of healthcare professionals after joining the EU were conducted in Poland, the Czech Republic, Hungary, Lithuania, Croatia, and Estonia [9-12].

The driving forces for the migration of healthcare professional in the EU are different. Jinks et al. [13] investigated the movement of doctors from EU countries to the UK and concluded that the main driving forces for migration to the UK were reduced employment chances in the home country or motivation to get a better training in the UK. In all the new EU member states (for example Poland, Hungary, Lituania, Estonia), the main motivation for emigrating is a better pay in the host country [12].

Romania, who is a member of EU since 2007, deals with a health workforce crisis linked to migration [14].

The public sector in Romania is undergoing dramatic changes as the state is coming to terms with the postCommunist era, with the (neo)liberalization encouraged further by the EU accession in 2007, and with the impact of austerity measures implemented as a result of IMF loans in 2010 [15]. In the past few years, the situation in the public health system has been affected by a mix of contributing factors, including limiting economic measures, a public sector salary cut of $25 \%$, a recruitment freeze, and budget constraints on hospitals' staffing. In this context, Romania may primarily be thought as the "sender" country of migrant health workers to Western Europe. The brain drain of the Romanian elite is nowadays considered a "fourth wave" of migration as of 1989, with the medical profession being one of the most prominent occupations mentioned in migration studies [16].

Europe's aging population, the free movement of labor, and mutual recognition of qualifications are creating new opportunities for Romanian medical doctors, while inadequate working conditions and relatively low salaries push many high-skilled healthcare workers to search for employment abroad. As the living standard in the Western EU member states exceeds the living standard of the new ones, economic incentives to move abroad are high, thus contributing to inequalities in the healthcare provision between them [7]. For example, a resident in Romania earns around 200 Euros, whereas residents in other EU countries can earn much more. [14].

Obtaining accurate data on migration of healthcare workers is highly problematic in Romania [14]. Official data is limited to the number of certificates of conformity for practicing medicine in the EU (although these requests do not automatically imply the migration of the health professionals). The main indicator is the "intention to leave" collected by the Romanian College of Physicians [14, 17]. Intention-to-leave data from Romania seems to indicate continuing high outflows of medical doctors, more than 300 certificates per month were issued to Romanian medical doctors in 2010 [18]. In 2014, 2450 certificates of conformity were issued. Therefore, this number can serve as an estimate for the number of doctors who left Romania for work abroad in 2014.

A further complication is the legal right in the public sector to solicit up to 2 years of unpaid leave of absence with no obligation to disclose purpose or destination. This enables staff to try out the options of working abroad, to take short overseas contracts, and ultimately to resign if they find a successful long term job abroad [19].

Another indirect indicator is the total number of registered doctors in Romania. This number was 39000 in 2014. The total number of doctors in Romanian hospitals has steadily decreased from 20648 doctors in 2011 to 14487 in 2012 and to 13521 doctors in 2014 [19]. The Romanian College of Physicians reported that "between 2007 and 2013, 14,000 medical doctors left their jobs in the national public health system and chose to practice abroad" [14].

A considerable public concern has been raised in Romania after the 2007 EU accession. An important emigration wave was predicted, especially among highly educated young professionals [16]. In an analysis of massmedia statements, Toader [20] indicates the media awareness of a large number of healthcare workers who left for other EU host countries since Romania's accession. Among the headlines quoted, we can mention statements like: " 4,000 doctors left the country in the past 2 years and almost 5,000 others are also ready to leave it" [21] and "The doctors' exodus will determine the collapse of the healthcare system in less than 10 years" [22].

Similar predictions about the potential disaster of physician migration were formulated for other new EU member states after the accession [23, 24]. However, they turned out to be overestimations, since the annual outflows from the new member countries rarely exceeded $3 \%$ of the domestic healthcare workforce [18].

Hardy et al. [15], based on previously published figures $[25,26])$, estimate that $3 \%$ of doctors and $5 \%$ of nurses leave the country each year. However, this number may be underestimated, as 20 to $40 \%$ of the total health worker population expresses a desire to work abroad.

\section{Methods}

\section{Aim of the study}

As there is considerable uncertainty about the magnitude of the Romanian physicians' exodus, we performed a survey to assess the emigration intention of future Romanian doctors. The study was conducted over three consecutive years: 2013, 2014, and 2015. 


\section{Sample}

The subjects of this study were 957 Romanian citizens, graduates of the faculty of medicine, who studied medicine in the Romanian language at the University of Medicine and Pharmacy "Iuliu Hatieganu".

Inclusion criteria: medical school graduates who are Romanian citizens and who passed the theoretical and practical test of the license exam.

Exclusion criteria: medical school graduates who are not Romanian citizens and medical school students who are Romanian citizen but failed on the theoretical or practical tests of the license exam.

\section{Procedure}

The study was conducted in close collaboration with the student organization, we held several sessions with the leaders of the students in order to communicate information about the purpose of the study. During the university years, one third of the students also participated in counseling sessions on specialty choice and they were also notified about this study.

The questionnaire was distributed to students during the licensing exam, before the public defense of theirs dissertations. The students were invited to participate after the survey's purpose and administration issues were explained. Participation in the survey was voluntary. Students did not receive any incentives to participate in the study. For the students, the direct benefit of participation in this research was the opportunity to express an opinion about a subject that is of interest to them: where they will be practicing medicine after residency and to contribute to the collection of data that could shape the public policy regarding health workforce in Romania.

The study received the approval of the Research Ethics Committee of our University. Response rate was $100 \%$.

\section{Questionnaire}

The self-administrated questionnaire (Additional file 1) used for the study includes 21 questions regarding students' emigration intention. The questions were centered on willingness to go work abroad and the possible reasons for such a decision. Participants were asked to specify how advanced their plan to work abroad was, when and for how long they planned to go. Several other questions on push and pull factors for migrations, the target country, and job preference were asked. In addition, demographic data about the students were collected (see Additional file 1).

\section{Statistical analysis}

Descriptive statistical analysis was performed to calculate means, standard deviations, and frequency. The distribution of the studied variables was examined using Shapiro-Wilk's and Kolmogorov-Smirnov's tests. Statistical significance was assumed at $p<0.05$. The Mann-Whitney $U$ test and Kruskal-Wallis test was used to compare groups with nonnormal distributions. Chi-square was used to compare frequencies. The analysis was performed in SPSS version 20.

\section{Results}

\section{Characteristics of the population}

The study included 957 students, females made up $71.5 \%$ of the sample; 824 students (86.1\%) came from urban environments (Table 1). Regarding relationship status, $58.2 \%$ of the students were single, $31.8 \%$ in a relationship, and $10 \%$ were married. The majority of students' parents (62.3\% of mothers and $65.3 \%$ of fathers) had a university degree, $19.9 \%$ of students' parents were doctors. The student's age ranged from 24 to 34 years, with the mean age $25.03( \pm 1.01)$ years. The students assessment of their household economic situation was $2.6 \%$ living in precarious conditions, $23.5 \%$ that cannot afford everything needed for a normal life, $66.7 \%$ that can afford everything needed for a normal life, and $7.2 \%$ that can consume without any restrictions. $31.2 \%$ of the participants desired to work in a hospital setting, $1.8 \%$ in a public outpatient practice, $10.1 \%$ aspired to work in a private practice, while $56.8 \%$ wanted to work in both a hospital setting and a private practice.

\section{Desire to emigrate}

Table 2 shows the distribution of intention and willingness to work abroad. $84.8 \%$ of the respondents have more or less developed a plan to seek employment abroad after

Table 1 Characteristics of the population

\begin{tabular}{|c|c|c|c|c|c|c|c|c|}
\hline & \multicolumn{2}{|c|}{2013} & \multicolumn{2}{|c|}{2014} & \multicolumn{2}{|l|}{2015} & \multicolumn{2}{|l|}{ Total } \\
\hline & $N$ & $\%$ & $N$ & $\%$ & $\bar{N}$ & $\%$ & $\bar{N}$ & $\%$ \\
\hline \multicolumn{9}{|l|}{ Gender } \\
\hline Male & 89 & 27.8 & 87 & 27.0 & 97 & 30.8 & 273 & 28.5 \\
\hline Female & 231 & 72.2 & 235 & 73.0 & 218 & 69.2 & 684 & 71.5 \\
\hline \multicolumn{9}{|l|}{ Residence } \\
\hline Urban & 268 & 83.8 & 278 & 86.3 & 278 & 88.3 & 824 & 86.1 \\
\hline Rural & 52 & 16.2 & 44 & 13.7 & 11.7 & 37 & 13.9 & 133 \\
\hline \multicolumn{9}{|l|}{ Relationship status } \\
\hline Single & 174 & 54.4 & 197 & 61.2 & 186 & 59.0 & 557 & 58.2 \\
\hline In a relationship & 110 & 34.4 & 94 & 29.2 & 100 & 31.7 & 304 & 31.8 \\
\hline Married & 36 & 11.2 & 31 & 9.6 & 29 & 9.2 & 96 & 10.0 \\
\hline \multicolumn{9}{|c|}{ Economic situation of the household } \\
\hline $\begin{array}{l}\text { Living in precarious } \\
\text { conditions }\end{array}$ & 10 & 3.1 & 10 & 3.1 & 5 & 1.6 & 25 & 2.6 \\
\hline Can manage generally & 90 & 28.1 & 72 & 22.4 & 63 & 20.0 & 225 & 23.5 \\
\hline $\begin{array}{l}\text { Can afford everything } \\
\text { needed for a normal life }\end{array}$ & 202 & 63.1 & 225 & 69.9 & 211 & 67.0 & 638 & 66.7 \\
\hline $\begin{array}{l}\text { Can consume without } \\
\text { restriction }\end{array}$ & 18 & 5.6 & 15 & 4.7 & 36 & 11.4 & 69 & 7.2 \\
\hline
\end{tabular}


Table 2 Distribution of medical students planning to work abroad

\begin{tabular}{|c|c|c|c|c|c|c|c|c|}
\hline & \multicolumn{2}{|c|}{2013} & \multicolumn{2}{|c|}{2014} & \multicolumn{2}{|c|}{2015} & \multicolumn{2}{|l|}{ Total } \\
\hline & $N$ & $\%$ & $N$ & $\%$ & $N$ & $\%$ & $N$ & $\%$ \\
\hline Do not want to go & 48 & 15 & 49 & 15.2 & 49 & 15.6 & 146 & 15.3 \\
\hline Vague plan & 99 & 30.9 & 110 & 34.2 & 99 & 31.4 & 308 & 32.2 \\
\hline Developed plan & 121 & 37.8 & 114 & 35.4 & 129 & 41.1 & 364 & 38 \\
\hline Definite plan & 52 & 16.2 & 49 & 15.2 & 38 & 12.1 & 139 & 14.5 \\
\hline Total & 320 & 100 & 322 & 100.0 & 315 & 100 & 957 & 100 \\
\hline
\end{tabular}

graduation. Respondents were asked to estimate the probability of migrating on a $0-100$ scale (ranging from $0-\mathrm{I}$ don't want to leave, 25-unlikely to leave, 50-likely to leave, to 100-definite leaving intentions) (Table 3). The average probability to emigrate was $42.17 \%$ ( \pm 30.24$)$, with no significant difference between males and females (Man-Whitney $U=39690.00, p=0.510$ ). $15.2 \%$ of the students estimate a 0 probability to leave, $34.2 \%$ a 25 probability score, $35.4 \%$ a 50 probability score, and $15.2 \%$ estimate the probability to emigrate at 100 .

The percentages of students who want to leave Romania stay rather constant across the years (around 15\% for the students who do not want to go, around $30 \%$ for those with a vague plan, around $35-40 \%$ for those with a developed plan, and around 15\% for those with a definite plan). This relatively stable distribution can suggest that there are no major changes to be expected. The 3\% dip in de definite plan category in 2015 is something to be monitored in the coming years. Based on the data available so far, the dip in 2015 could be attributed to a cohort effect.

Timeframe for migration, preferred length of stay abroad, and host country

$21.2 \%$ of the students plan to leave 1 year after graduation, $34.6 \%$ intend to leave within 2 to 3 years after graduation, and $9.4 \%$ do not even foresee to pass a residency training

Table 3 Timeframe for migration

\begin{tabular}{|c|c|c|c|c|c|c|c|c|}
\hline & \multicolumn{2}{|c|}{2013} & \multicolumn{2}{|c|}{2014} & \multicolumn{2}{|c|}{2015} & \multicolumn{2}{|c|}{ Total } \\
\hline & $N$ & $\%$ & $N$ & $\%$ & $N$ & $\%$ & $N$ & $\%$ \\
\hline I don't plan to leave & 48 & 15 & 49 & 15.2 & 49 & 15.6 & 146 & 15.3 \\
\hline $\begin{array}{l}\text { I will leave as soon as } \\
\text { I graduated }\end{array}$ & 38 & 11.9 & 33 & 10.2 & 19 & 6 & 90 & 9.4 \\
\hline $\begin{array}{l}\text { In the first year of } \\
\text { residency training }\end{array}$ & 52 & 16.2 & 108 & 33.6 & 43 & 13.7 & 203 & 21.2 \\
\hline $\begin{array}{l}\text { In the } 2-3 \text { year of } \\
\text { residency training }\end{array}$ & 136 & 42.5 & 65 & 20.2 & 130 & 41.3 & 331 & 34.6 \\
\hline After specialization & 21 & 6.6 & 33 & 10.2 & 38 & 12.1 & 92 & 9.6 \\
\hline $\begin{array}{l}\text { After I work a few } \\
\text { years in Romania }\end{array}$ & 25 & 7.8 & 34 & 10.6 & 36 & 11.4 & 95 & 9.9 \\
\hline Total & 320 & 100 & 322 & 100.0 & 315 & 100 & 957 & 100 \\
\hline
\end{tabular}

admission exam in Romania. Only $15.3 \%$ of the students do not have any plans for migration (see Table 2).

Most students want to go abroad for a short period $-35.2 \%$ plan to stay abroad a few months, $26.1 \%$ intent to stay abroad for several years and then come back to practice in Romania, and $23.4 \%$ of the students have a permanent emigration plan (see Table 4). Among the students who are planning to emigrate the preferred host countries are Germany (34.1\%), France (20.0\%), and Great Britain (19.6\%). 28.5\% of the student do not know yet to which country they want to emigrate.

\section{Concrete departure preparation}

The students who plan to emigrate have taken concrete steps towards emigration goals, including spending time abroad in Erasmus student mobility (21.7\%), enrolling in language courses $(44.5 \%)$, searching jobs on the Internet (42.7\%), participating in job fairs for healthcare professionals (40.1\%), and contacting Romanian physicians who are working abroad (75.2\%). There are significant differences in the level of preparation between the students who plan to emigrate and the students who do not want to leave Romania (see Table 5).

\section{The factors influencing the migration decision}

In this section, we are giving an account of the main factors influencing the decision to work abroad. These factors could be the potential subjects of inquiry for health policy developers if the general aim is the reduction of the prospective migration flows of Romanian healthcare professionals. Respondents were asked to rank the following reasons for resettlement on a $0-100$ scale: higher wage abroad; better living and working condition abroad; I am disappointed with the Romania healthcare system; to gain living and working experience abroad; personal reason (my partner want to work/is working abroad); more professional opportunities; shortage of residency opportunities in my chosen specialty in Romania; and lack of job vacancies in my chosen specialty in Romania (see Table 6).

As a main pull factor for migration (see Table 6), students who want to emigrate highly rank the elevated wages and better living and working conditions abroad $(88.91 \pm 34.58$ and $82.57 \pm 22.52)$. Similarly, they rank

Table 4 Preferred length of stay abroad

\begin{tabular}{|c|c|c|c|c|c|c|c|c|}
\hline & \multicolumn{2}{|c|}{2013} & \multicolumn{2}{|c|}{2014} & \multicolumn{2}{|c|}{2015} & \multicolumn{2}{|c|}{ Total } \\
\hline & $N$ & $\%$ & $N$ & $\%$ & $N$ & $\%$ & $N$ & $\%$ \\
\hline I don't plan to leave & 48 & 15 & 49 & 15.2 & 49 & 15.6 & 146 & 15.3 \\
\hline For several months & 108 & 33.8 & 109 & 33.9 & 120 & 38.1 & 337 & 35.2 \\
\hline For several years & 83 & 25.9 & 93 & 28.9 & 74 & 25.3 & 250 & 26.1 \\
\hline Permanently & 81 & 25.3 & 71 & 22 & 72 & 22.9 & 224 & 23.4 \\
\hline Total & 320 & 100 & 322 & 100.0 & 315 & 100 & 957 & 100 \\
\hline
\end{tabular}


Table 5 Cross tabulation of concrete departure preparation and migration intention

\begin{tabular}{|c|c|c|c|c|c|c|}
\hline \multicolumn{3}{|c|}{ Concrete departure preparation } & \multicolumn{2}{|c|}{ Migration intention } & \multirow[t]{2}{*}{$x^{2}$} & \multirow[t]{2}{*}{$p$} \\
\hline & & & $\begin{array}{l}\text { Do not } \\
\text { emigrate }\end{array}$ & $\overline{\text { Emigrate }}$ & & \\
\hline \multirow{4}{*}{$\begin{array}{l}\text { Taking part in Erasmus } \\
\text { student mobility }\end{array}$} & \multirow[t]{2}{*}{ No } & $N$ & 138 & 635 & \multirow[t]{4}{*}{20.96} & \multirow[t]{4}{*}{0.000} \\
\hline & & $\%$ & 94.5 & 78.3 & & \\
\hline & \multirow[t]{2}{*}{ Yes } & $N$ & 8 & 176 & & \\
\hline & & $\%$ & 5.5 & 21.7 & & \\
\hline \multirow{4}{*}{$\begin{array}{l}\text { Enrolling in language } \\
\text { courses }\end{array}$} & \multirow[t]{2}{*}{ No } & N & 110 & 450 & \multirow[t]{4}{*}{20.09} & \multirow[t]{4}{*}{000} \\
\hline & & $\%$ & 75.3 & 55.5 & & \\
\hline & \multirow[t]{2}{*}{ Yes } & $N$ & 36 & 361 & & \\
\hline & & $\%$ & 24.7 & 44.5 & & \\
\hline \multirow[t]{4}{*}{ Job search on the Internet } & \multirow[t]{2}{*}{ No } & $N$ & 115 & 465 & \multirow[t]{4}{*}{23.8} & \multirow[t]{4}{*}{0.000} \\
\hline & & $\%$ & 78.8 & 57.3 & & \\
\hline & \multirow[t]{2}{*}{ Yes } & $N$ & 31 & 346 & & \\
\hline & & $\%$ & 21.2 & 42.7 & & \\
\hline \multirow{4}{*}{$\begin{array}{l}\text { Jobs fairs for healthcare } \\
\text { professionals }\end{array}$} & \multirow[t]{2}{*}{ No } & N & 117 & 486 & \multirow[t]{4}{*}{21.64} & \multirow[t]{4}{*}{0.000} \\
\hline & & $\%$ & 80.1 & 59.9 & & \\
\hline & \multirow[t]{2}{*}{ Yes } & N & 29 & 325 & & \\
\hline & & $\%$ & 19.9 & 40.1 & & \\
\hline \multirow{4}{*}{$\begin{array}{l}\text { Talking with Romanian } \\
\text { physicians who are } \\
\text { working abroad }\end{array}$} & \multirow[t]{2}{*}{ No } & $N$ & 59 & 201 & \multirow[t]{4}{*}{15.26} & \multirow[t]{4}{*}{0.000} \\
\hline & & $\%$ & 40.4 & 24.8 & & \\
\hline & \multirow[t]{2}{*}{ Yes } & $N$ & 87 & 610 & & \\
\hline & & $\%$ & 59.6 & 75.2 & & \\
\hline
\end{tabular}

their discontent with the Romanian healthcare system $(77.44 \pm 34.47)$. Another important factor is the lack of working places in Romania $(54.35 \pm 37.88)$. The least frequently reported migration factor is relationship status (my partner wants to work/is working abroad), with an average of $25.17 \pm 33.51$. We find significant differences between the students who want to emigrate and the ones who do not want to emigrate.
The majority of students are not satisfied with the anticipated salaries they could earn working in the Romanian (implicitly) public health system (see Table 7).

The Spearman's rho correlation coefficient between the concrete departure preparation (the variable is a sum of all "yes" answers to possible actions, like Erasmus mobility, language courses, job search, contacts with Romanian physicians working abroad) and reason for migration was 0.314 , with $p<0.01$.

The students who are determined to migrate score higher on reasons for migration total score and on concrete departure plans (see Table 8).

\section{Discussion}

This is the first study of its kind in Romania, aiming to provide an in-depth analysis of prospective physician migration, with a particular emphasis on the attitudes and practices undertaken by medical graduates in relation to choosing a career abroad.

In this study, $84.7 \%$ of the respondents are considering to seek employment abroad after graduation. The total percentage of students that are considering emigration $(84.7 \%)$ is higher than in other Eastern European countries. For comparison, Polish students estimated the likelihood of emigration to be around 50\% [11]. 60\% of medical residents from Lithuania stated that they intended to emigrate, $15 \%$ of them permanently [27], and only $45 \%$ of the Czech physicians are contemplating emigration [28]. One third of the final year medical students from Croatia reported their willingness to permanently leave the country in search of employment elsewhere [10]. In 2004, surveys conducted in Central and Eastern Europe found that $10.4 \%$ of Polish, $15.6 \%$ of Czech, and as many as $24.7 \%$ of Hungarian physicians contemplated migration [12]. Interestingly, these forecasts often seem to overestimate the true rate of emigration, as joining the EU was rarely associated with a percentage of emigrated physicians higher than $3 \%$ [18].

Table 6 Reasons for migration

\begin{tabular}{|c|c|c|c|c|c|}
\hline & \multicolumn{2}{|c|}{ Do not emigrate } & \multicolumn{2}{|c|}{ Emigrate } & \multirow{2}{*}{$\begin{array}{l}\text { Man-Whitney } \\
\text { Up }\end{array}$} \\
\hline & Mean & Std. deviation & Mean & Std. deviation & \\
\hline Higher wage abroad & 61.62 & \pm 37.94 & 82.57 & \pm 22.52 & 0.000 \\
\hline Better working and living condition abroad & 65.84 & \pm 37.28 & 88.91 & \pm 34.58 & 0.000 \\
\hline I am disappointed in the healthcare system in Romania & 68.24 & \pm 34.35 & 77.44 & \pm 34.47 & 0.000 \\
\hline To gain living and working experience abroad & 31.5 & \pm 31.42 & 59.61 & \pm 30.95 & 0.000 \\
\hline Relationship status & 12.94 & \pm 24.12 & 25.17 & \pm 33.51 & 0.000 \\
\hline More professional opportunities & 46.27 & \pm 35.16 & 73.08 & \pm 27.02 & 0.000 \\
\hline Shortage of residency places in my chosen specialty & 21.37 & \pm 31.51 & 35.85 & \pm 35.72 & 0.000 \\
\hline Lack of working places in my chosen specialty & 26.41 & \pm 33.89 & 54.35 & \pm 37.88 & 0.000 \\
\hline Total score & 3344.22 & \pm 239.33 & 472.17 & \pm 158.86 & 0.000 \\
\hline
\end{tabular}


Table 7 Distribution of satisfaction with anticipated salaries in the Romanian health system (\%)

\begin{tabular}{lll}
\hline & $N$ & $\%$ \\
\hline Not satisfied at all & 341 & 35.6 \\
Rather not satisfied & 470 & 49.1 \\
Quite satisfied & 59 & 6.2 \\
Very satisfied & 5 & 0.5 \\
Difficult to say & 82 & 8.6 \\
Total & 957 & 100.0 \\
\hline
\end{tabular}

Regarding the Romanian sample, female alumni made up the majority of our sample. This is due to the fact that a higher number of female students are enrolled for medical studies. The top destination choice among those who wish to emigrate is Germany (with $34.1 \%$ ). Among reasons for pursuing a career abroad, the mean score for "higher wage than in Romania" was most notable. There were no gender or marital status differences in correlation with the importance of a better payment abroad. In Romania, public health sector wages represent, on average, around $15 \%$ of the levels typically paid in the old EU member states, and even if differences in the living cost are taken into account, migration provides an attractive financial gain [15].

Other reasons for migration included disagreement with the Romanian healthcare and residency system, as well as better prospective quality of life abroad. In the past few years, the tradition of Romanian informal, "under-thetable" payments offered by patients to doctors and nurses has been highlighted in the media in a manner that vilifies the medical professions and this bad press is seen as a

Table 8 Relationship between the departure plans, professional dissatisfaction and migration intention

\begin{tabular}{|c|c|c|c|}
\hline & & $\begin{array}{l}\text { Reasons for } \\
\text { migration一total } \\
\text { score }\end{array}$ & $\begin{array}{l}\text { Concrete departure } \\
\text { plans-total } \\
\text { score }\end{array}$ \\
\hline \multirow{3}{*}{$\begin{array}{l}\text { Do not want } \\
\text { to go }\end{array}$} & Mean & 334.22 & 1.36 \\
\hline & $N$ & 146 & 146 \\
\hline & Std. deviation & 239.33 & 1.02 \\
\hline \multirow[t]{3}{*}{ Vague plan } & Mean & 474.87 & 2.55 \\
\hline & $N$ & 308 & 308 \\
\hline & Std. deviation & 126.712 & 1.38 \\
\hline \multirow[t]{3}{*}{ Developed plan } & Mean & 505.10 & 4.26 \\
\hline & $N$ & 364 & 364 \\
\hline & Std. deviation & 111.53 & 1.44 \\
\hline \multirow[t]{3}{*}{ Definite plan } & Mean & 524.79 & 4.74 \\
\hline & $N$ & 139 & 139 \\
\hline & Std. deviation & 142.89 & 1.47 \\
\hline Kruskal-Wallis W & & 119.81 & 399.69 \\
\hline$p$ & & 0.000 & 0.000 \\
\hline
\end{tabular}

further possible reason for dissatisfactions and consequently for the migration of young doctors [15].

In our study, practice preferences upon graduation indicate that about $33 \%$ of the medical alumni desire to practice exclusively in the public sector rather than the private sector (10.1\%). Another 56.8\% intend to work simultaneously in a public hospital setting and private practice. These preferences are expressed in the context of a constant decline of number of doctors practicing in Romanian public hospitals. The public hospitals present the number of doctors decreasing from 20648 in 2011, to 14487 in 2012, and to 13521 doctors in 2014 [19]. The main reason for health professionals to stay in the public sector may be for future training, academic tenure, and gaining experience before joining the private sector.

Loss at the societal level, caused by physicians' migration for work, must be understood in the wider context of the loss of an educated professional resource for which the costs for qualification are very high. The state invests in the education of a physician for a longer period of time and the costs are much higher than for other professions. Not to mention the fact that doctors and nurses are not easily replaceable. The direct, average, costs for the training of a physician are around 6660 Euros for undergraduate education and 4660 Euros for specialty training [29]. Theoretically, such a financial burden in a public educational system brings a serious issue of concern regarding the role of the state to damper the migration flow of health professionals.

At the public policy levels, the economic crisis and the lack of efficiency of the Romanian Administration have generated negative effects on the Romanian society. The massive white gown migration is a phenomenon new to Romania, and this type of migration is very different from the migration of unskilled workers. The long-term effects of this migration are not known yet, but might affect many people, especially the communities in small towns and rural areas, where poverty rates can be twice as high as in urban areas and where they do not have immediate access to a full time medical assistant/nurse or a doctor [14].

Physicians' migration for work can also turn into permanent migration much easier than previous waves of Romanian migration: as the doctors have better wages than unqualified workers and it is much easier for them to bring their family along. Therefore, losing 1000 doctors per years is a lot when comparing this number to the total number of doctors in Romania (39000 in total and 13521 working in the hospitals in 2014) [19]. This number raises serious questions regarding a possible national vulnerability caused by the emigration of Romanian health workers to the developed countries in Western Europe.

There are three main arguments used by physicians in favor of migration: low salary, the lack of social status 
and the continuous deterioration of the public perception, constant lack of government interest for investment, and appropriate public policies in the healthcare sector. A large number of the students who have participated in the study have already started preparing for emigration, $21.7 \%$ of those who wished to migrate had already performed at least one Erasmus mobility in their country of choice, $44.5 \%$ have been enrolled in a language course, and $42.7 \%$ have searched for jobs on the Internet.

The reasons for potential emigration among graduating medical students in Romania were similar to those reported in other European countries. For instance, major reasons for leaving Lithuania were higher salary, better professional opportunities, and better quality of life [27], similarly to the findings among Czech physicians [28] and students from Poland [11].

From an EU labor market perspective, free mobility of doctors can be a way to balance supply and demand for health workforce. Underemployment has led Romanian health professionals to seek work elsewhere in the EU. For destination countries, free mobility can contribute to health system performance when foreign health professionals fill services gaps [30]. In France, in 2007, 40\% of newly registered anesthetists and $20 \%$ of newly registered pediatricians were EU nationals, mainly from Romania [31].

Returning health professionals may increase expertise in the home system when they improve their skills and qualifications abroad [32]. From this perspective, 26.1\% of the students who declare they want to stay abroad for several years and then come back to practice in Romania may prove to be an asset.

Mobility can also provide a policy stimulus to tackle workforce issues. In 2010, some 3800 publicly employed Czech doctors joined the protest movement "Thank you, we're leaving," threatening to collectively resign and subsequently obtained salary increases and improvements to the educational system [30,33].

We didn't find any statistics regarding migration of physicians, how many, where they go, what age or professional experience, and where they graduated. Romania should further strengthen the availability of health workforce data, which should cover migration issues. This would facilitate policy and decision-making in Romania. Despite a large number of medical professionals having already migrated, it is unclear whether any of them returned, from where, and where they are currently employed (public or private health sector). A centralized database for health workforce data that tracks health worker mobility would allow for better public policy decisions [14].

Migration is an expression of liberty and individual choice. However, the state invests in the training of medical personnel and will lose this investment if the medical students will migrate after graduation. As a policy, the government could choose to try to penalize migration or to stimulate the retention of medical personnel in the country.

The Government could propose a tax on the migration of highly skilled medical personnel (the doctors will have to work in the country a certain number of year after graduation or reimburse the cost of education). But if this tax is proposed only for medical personnel, this will create discrimination and will be rejected as non-constitutional. Additionally, such a penalty goes against the EU principle of free circulation of workforce and free movement and therefore would not stand a chance in the EU Court of Justice. An alternative option would be to develop some bilateral agreements between Romania and the destination countries to arrange for some financial compensation. Open methods of coordination currently existent within the EU would provide different ways to arrange for such an option.

So far, confronted with situation created by the migration of doctors, the first measure of the Government was to raise the medical personal remuneration by $25 \%$ (Government Emergency Ordinance nr. 35/2015) starting with 1 October 2015. The effects of this measure will satisfy only the financial problems of the doctors. Still, the Government will need to invest in the equipment of the hospitals, training of physicians, and in abolishing corruptions in the medical system [34].

Structural reforms in the healthcare provisions are needed in order to facilitate the retention of medical personnel. The institution of contracts to retain the new graduates for 5 years can only lead to building resentment on behalf of the medical personnel affected by this measure and to costly and time-consuming juridical battles. The results of this research suggest that the primary concern remains related to personal finances. Therefore, the measures already taken to increase the salaries of medical personnel can be included as a first step towards the desired direction.

Next to addressing individual financial security, additional measures need to be taken in order to develop a healthcare system that provides attractive career options for the personnel (current and new graduates). Structural financial investments need to include financial support regarding professional integration of young professionals, coupled with facilitating the re-building access to medical care provision in small to medium size cities, and rural areas would provide attractive work options. Extensive measures to combat vilification of the medical profession in the media could help motivate young professional towards building their career in Romania. Additional measures could also include the support for professional 
integration of physicians and nurses who are working abroad back into the Romanian healthcare system.

\section{Strengths and limitations}

This study has a number of strengths. Firstly, the perfect response rate $(100 \%)$ decreases the likelihood of a response bias. Secondly, this is the first study describing the demographics of a large sample of graduates of a Romanian medical faculty.

The most important limitation to consider for our study is that it was restricted to just one main Romanian faculty of medicine. Although the studied alumni population is rather heterogeneous, with individuals coming from all regions of the country, it cannot predict the overall situation in Romania. This implies that further studies should be conducted on a larger scale, with other medical schools participating in the same survey, in order to minimize bias as well as to ensure a broader view of the current situation. Also, studies can be done on residents, who choose to migrate, to see the personal and professional factors that influence the decision to turn a temporary mobility for specialization in a permanent migration.

Assessing intentions, and not actual behavior, represents another limitation of this study. We were not able to identify in literature any study linking migration intention to actual migration behavior. However, even if we were to assume a less than strong association, the percentage of those intending to emigrate abroad is alarming in the general context of the actual migration of Romanian physicians.

Another limitation of the study is the deployment of quantitative data and the lack of nuance brought by qualitative data. In-depth ethnographic research could lead to a better understanding of personal drives of individuals as well as to a better understanding of the migration in the context of a globalized pressure on the health workforce to comply to new rules of the disempowerment of professionals under the pressure of the neoliberal world order.

\section{Conclusions}

The majority of Romanian medical students considering migration see it as a serious alternative to the continuation of their professional training started in Romania. The findings of this study are disturbing in terms of the future migration of Romanian physicians and have implications for both policymaking and future research. Romanian policy architects need to devise a comprehensive national health workforce plan to deal with physician migration. This should take into account the narratives and behaviors of both stayers and leavers. Such a plan should carefully address the financial incentives in the Romanian public sector, the recruitment freeze, status issues, and other factors contributing to the migration of physicians, such as the quality of residency training. Specific policies targeting medical students should prove beneficial in the long run, as the college life is the prime time for molding attitudes of future physicians. Special allocations or status reinforcements should be devised for those who do not intend to migrate in the future. There is a need for more research investigating the impact of migration on the effectiveness and efficiency of healthcare systems in both the home and host countries.

\section{Additional file}

Additional file 1: Questionaire regarding migration intent. (DOCX $41 \mathrm{~kb}$ )

\section{Acknowledgements}

We thank all medical students who participated in the survey. The authors would like to thank the following students: Radu Pârlog, 5th Year General Medicine, Romanian Section, who assisted with data collection and entry, Elisabeta Radulovivi, 4th Year General Medicine, and Edit Lupu, 1st Year English Section, who assisted with the correction of the English manuscript of this paper.

\section{Funding}

None to be declared.

This study did not receive any funds from any funding body; the University had paid for the printing of the questionnaires. The authors did not received any payment for the work in this research.

\section{Availability of data and materials}

The datasets generated during and/or analyzed during the current study are available from the corresponding author on reasonable request.

\section{Authors' contributions}

PC, BA, and SS developed the study proposal and survey tool. PC, BA, and SS were involved in the data collection. PC conducted the data analysis. $\mathrm{MC}$ contributed to the interpretation of findings and the writing of this paper. PC prepared all drafts and redrafts of the paper. All authors provided editorial comment on draft versions of the paper. All authors have read and approved the final manuscript.

\section{Competing interests}

The authors declare that they have no competing interests.

\section{Consent to publication}

Not applicable.

Ethics approval and consent to participate

Our study has been approves by the Ethics Committee of the University of Medicine and Pharmacy "Iuliu Hatieganu" approval number 189/23.05 2013.

\section{Author details}

'Department of Physiology, "Iuliu Hatieganu" University of Medicine and Pharmacy, Victor Babes Nr 8 Street, 400012 Cluj-Napoca, Romania.

'Department of Abilities-Human Sciences, "Iuliu Hatieganu" University of Medicine and Pharmacy, Victor Babes Nr 8 Street, 400012 Cluj-Napoca, Romania. ${ }^{3}$ Faculty of Psychology and Sociology, West University, Vasile Parvan Nr 8 Street, 00223 Timisoara, Romania. " Department of Pharmacology, Toxicology and Clinical Pharmacology, "Iuliu Hatieganu" University of Medicine and Pharmacy, Victor Babes Nr 8 Street, 400012 Cluj-Napoca, Romania.

Received: 16 August 2016 Accepted: 6 January 2017 Published online: 19 January 2017

\section{References}

1. Mejia A. Migration of physicians and nurses: a world wide picture. Int J Epidemiol. 1978;7(3):207-15. 
2. Gupta N, Diallo K, Zurn P, Dal Poz MR. Assessing human resources for health: what can be learned from labour force surveys? Hum Resour Health. 2003;1(1):5.

3. Mullan F. The metrics of the physician brain drain. N Engl J Med. 2005; 353(17):1810-8.

4. Chen L, Evans T, Anand S, Boufford Jl, Brown H, Chowdhury M, Cueto M, Dare L, Dussault G, Elzinga G, Fee E. Human resources for health: overcoming the crisis. Lancet. 2004;364(9449):1984-90.

5. Martineau T, Decker K, Bundred P. Briefing note on international migration of health professionals: levelling the playing field for developing country health systems. Liverpool: Liverpool School of Tropical Medicine. 2002 http://www.aspeninstitute.org/sites/default/files/content/images/martineau_ 0.pdf . Accessed 15 Jan 2015.

6. Buchan J, Sochalski J, Parkin T. International nurse mobility: trends and policy implications. In: Institutional Repository for Information Sharing. World Health Organization. 2003. http://apps.who.int/iris/handle/10665/ 68061 . Accessed 15 Jan 2015.

7. Forcier MB, Simoens S, Giuffrida A. Impact, regulation and health policy implications of physician migration in OECD countries. Hum Resour Health. 2004;2(1):12

8. Buchan J, Glinos IA, Wismar M. Introduction to health professional mobility in a changing Europe. In: Buchan J, Wismar M, Glinos IA, Bremner J, editors. Health Professional Mobility in a Changing Europe: new dynamics, mobile individuals and diverse responses. Observatory Studies Series 32. Copenhagen: WHO; 2014.

9. Borzeda A, Bonlarron AG, Gregorie-Borzeda C, Precahowa N. European enlargement: do health professionals from candidate countries plan to migrate? The case of Hungary, Poland and the Czech Republic. Paris: Ministry of Social Affairs, Labour and Solidarity; 2002.

10. Kolčić I, Čikeš M, Boban K, Bućan J, Likić R, Ćurić G, Đogaš Z, Polašek O. Emigration-related attitudes of the final year medical students in Croatia: a cross-sectional study at the dawn of the EU accession. Croat Med J. 2014; 55(5):452-8

11. Krajewski-Siuda K, Szromek A, Romaniuk P, Gericke CA, Szpak A, Kaczmarek K. Emigration preferences and plans among medical students in Poland. Hum Resour Health. 2012;10:8. doi:10.1186/1478-4491-10-8.

12. Võrk A, Kallaste $E$, Priinits M. Migration intentions of health care professionals: the case of Estonia. Cluj Napoca: Public Policy Center; 2004.

13. Jinks C, Ong BN, Paton C. Mobile medics? The mobility of doctors in the European Economic Area. Health Policy. 2000;54(1):45-64.

14. Paina L, Ungureanu M, Olsavszky V. Implementing the Code of Practice on International Recruitment in Romania-exploring the current state of implementation and what Romania is doing to retain its domestic health workforce. Hum Resour Health. 2016;14(Suppl1):22. doi:10.1186/s12960-016-0119-6.

15. Hardy J, Calveley M, Shelley S, Zahn R. Opportunities and challenges related to cross border mobility and recruitment of the health sector workforce. In EPSU Report Migration of Health Workers Summary Recommendations. European Public Service Union. 2012. http://www.epsu.org/sites/default/ files/article/files/EPSU-Report-Migration-Health-Workers-Summary_ Recommandations-EN.pdf. Accessed 15 Aug 2016.

16. Ulrich L, Stanciugelu S, Bojinca M, Mihaila V. Al patrulea val. Migrația creierelor pe ruta România-Occident, [The 4th Wave. Migration of brain from Romania to Occident] In: Alexe I, (ed.). Fundatia pentru o societate deschisa. [Open Society Fundation]. 2011. http://www.fundatia.ro/alpatrulea-val-migrația-creierelorpe-ruta-românia-occident. Accessed 15 Jan 2015.

17. Wismar M, Maier C, Glinos I, Dussault G, Figueras J. Health professional mobility and health systems. Observatory studies series. Brussels: European Observatory on Health Systems and Policies; 2011.

18. Ognyanova D, Maier CB, Wismar M, Girasek E, Busse R. Mobility of health professionals pre and post 2004 and 2007 EU enlargements: evidence from the EU project PROMeTHEUS. Health Policy. 2012;108(2-3):122-32. doi:10. 1016/j.healthpol.2012.10.006. Epub 2012 Nov 13.

19. Colegiul Medicilor. Comunicat de presa 34. [Romanian College of Physicians, Press release Nr. 34], In Colegiul Medicilor. 2014. http://www.viata-medicala. ro/*articlelD_11373-dArt.html. Accessed 15 Dec 2016.

20. Toader E. Current opinions of doctors and decisional factors on the migration of the Romanian physicians: a study of several mass-media statements. RCIS. 2012:37:144-61.
21. Robu D. France Presse: Dilema medicilor romani - Să plec sau să raman în tară?, [France Presse: Romanian doctors dilemma—should I leave or should I stay in the country], In Ziare.com. 2010. http://www.ziare.com/stiri/spitale/ france-presse-dilema-medicilor-romani-sa-plec-sau-sa-raman-in-tara-1061884 Accessed 15 Aug 2016.

22. Pașca C. Exodul medicilor va determina în maximum 10 ani colapsul sistemului de sănătate, [The exodus of doctors will case the collapse of the medical system in 10 years], In Ziarul de lasi. 2008. http://www.ziaruldeiasi. ro/invatamant/exodul-medicilor-va-determina-in-maximum-10-ani-colapsulsistemului-de-sanatate ni4lo0 . Accessed 15 Aug 2016.

23. García-Pérez MA, Amaya C, Otero Á. Physicians' migration in Europe: an overview of the current situation. BMC Health Serv Res. 2007;7:201.

24. Krosnar K. Could joining EU club spell disaster for the new members? BMJ. 2004;328(7435):310.

25. Vladescu C, Olsavky V. Migration of nurses: the case of Romania. Manag Health. 2010;25:13(4)

26. Galan A, Olsavszsky V, Vladescu C. Emerging challenges after EU accession: Romania. Euro Observer: The health policy bulletin of the European observatory on health systems and policies. 2011;13(2):10-1.

27. Stankūnas $M$, Lovkyte L, Padaiga $Z$. The survey of Lithuanian physicians and medical residents regarding possible migration to the European Union. Medicina (Kaunas, Lithuania). 2003:40(1):68-74. https://www.ncbi.nIm.nih. gov/pubmed/14764985

28. Hnilicová H, Vavrecková J, Dobiásová K. Migration trends of Czech physicians. Cas Lek Cesk. 2007;147(1):49-54. https://www.ncbi.nlm.nih.gov/ pubmed/18323043

29. Chitul M. Statul a pierdut deja 160 milioane de Euro din plecarea medicilor in Occident, [The State has already lost 160 millions Euro from the doctors leaving in the Western Countries], In Gândul. 2013. http://www.gandul.info/ stiri/statul-a-pierdut-deja-160-de-milioane-de-euro-din-plecarea-medicilor-inoccident-cat-costa-formarea-unui-medic-si-cum-au-ajuns-doctorii-romani-sacucereasca-franta-10978255. Accessed 15 Aug 2016.

30. Glinos I. Health professional mobility in the European Union: exploring the ethics and efficiency of free movement. Health Policy. 2015;119:1529-36.

31. Delamaire ML, Schweyer FX. Nationally moderate, locally significant:France and health professional mobility from far and near. In: Wis-mar M, Maier CB, Glinos IA, Dussault G, Figueras J, editors. Healthprofessional mobility and health systems: evidence from 17 Euro-pean countries. Observatory Studies Series 23. Copenhagen: WHO Regional Office for Europe on behalf of the European Observatory on Health Systems and Policies; 2011.

32. Lopez-Valcarcel BG, Perez PB, Quintana CDD. Opportunities in anexpanding health service: Spain between Latin America and Europe. In: Wismar M, Maier CB, Glinos IA, Dussault G, Figueras J, editors. Health professional mobility and health systems: evidence from 17 European countries. Observatory Studies Series 23. Copenhagen: WHO Regional Office for Europe on behalf of the European Observatory on Health Systems and Policies; 2011

33. Alexa J, Recka L, Votápková J, van Ginneken E, Spranger A, Witten-becher F. Czech Republic: health system review. Health Syst Trans. 2015;17(1):1-165. In WHO Europe. 2015. http://www.euro.who.int/_data/assets/pdf_file/0005/ 280706/Czech-HiT.pdf . Accessed 15 Aug 2016.

34. Government Emergency Ordinance no. 35/2015 regarding the amendment and supplementing Government Emergency Ordinance no. 83/2014 on remuneration of personnel paid from public funds in. 2015. http://www. lexmed.ro/doc/OUG 35 2015.pdf. Accessed 5 Dec 2016. 